\title{
Lía Schwartz en el recuerdo
}

Juan Diego Vila

Universidad de Buenos Aires, Argentina

Cita sugerida: Vila, J. D. (2019). Lía Schwartz en

el recuerdo. Olivar, 20(31), e080.

https://doi.org/10.24215/18524478e080

El pasado 31 de mayo nos llegó la muy triste noticia del fallecimiento de Lía Schwartz (Corrientes, 1941Nueva York, 2020). Genuinas muestras de dolor y pena se fueron sucediendo, casi sin mediación, al modo de obituarios, necrológicas y semblanzas, con hermosos textos de circulación masiva o institucional y también soportes audiovisuales que procuraron cifrar, con la calidez y admiración que su persona merecía, a quien fuera en vida ejemplar e incansable investigadora, docente dedicada y lectora infatigable.

Lo propio de Lía, su marca distintiva en un universo académico cada día más volcado a los particularismos, a los compartimentos estancos y a la jerarquización distorsiva de inéditos, fue la delicada labor de fina articulación de dos universos culturales que había aprendido a amar en sus años de formación en la Universidad de Buenos Aires: el de las antigüedades grecolatinas y el de los autores clásicos españoles de los siglos XVI y XVII.

Y no es dato menor ni azaroso el que, en su modo de entender la filología y la práctica académica, diversas señas de afiliación con sus maestros bonaerenses hayan pervivido. Todos han recordado sus clases con Jorge Luis Borges sobre literatura inglesa clásica, mas ella atesoraba, con análoga valoración, el impacto de sus maestros de latín y griego (Adolfo Prieto, Eihardt Schlessinger y Guillermo Thiele), las clases de gramática e introducción a la literatura de Ana María Barrenechea y la oportunidad de haber participado del último curso de postgrado que impartió en Argentina la malograda María Rosa Lida de Malkiel en 1962 sobre líricos renacentistas.

Luces y sombras perfilan, desde esta terra australis, su recuerdo puesto que el prolijo hilván de todo lo logrado profesionalmente en ámbitos internacionales con posterioridad, dice también, para quien quiera oírlo, la pérdida sustantiva de tantas casas de estudio nacionales que, cuando 'la noche de los bastones largos', terminaron expulsando de sus claustros -y del país- a eminente pléyade de académicos de las más variadas 
disciplinas. Lía, junto a su querido Isaías Lerner, fue una más de ese sombrío contingente. Y si bien en reiteradas ocasiones los dos pensaron en reinstalarse en Buenos Aires junto a su hija Betina, lo cierto es, sin embargo, que la complejidad y particulares circunstancias de los exilios no habilitaron, en todas las ocasiones, segundas oportunidades.

Mas también es justo precisar, allende la nostalgia que su ausencia pudo haber producido durante tantos años, cómo, en cada retorno a su país, obró generosamente con tantos colegas que reencontró o comenzaba a conocer, cómo, desde su posición central en tantísimas asociaciones profesionales, buscó potenciar y volver conocido el hispanismo argentino del que se sentía heredera.

Lía floreció profesionalmente en distintas universidades de Estados Unidos (Fordham University, Princeton University, Dartmouth College, The Graduate Center of The City University of New York). En todas ellas hizo gala de una capacidad de resilencia única. Enseñó español cuando no era conocida, impartió los cursos que otros le asignaban o vivió en otra ciudad en ocasiones en que, legalmente, las casas de estudios norteamericanas impedían que dos cónyuges integraran el mismo departamento. Pero nada la detuvo. Al punto que podríamos decir que hizo carne el tópico cervantino de las 'adversidades provechosas':supo hacer de cada contratiempo existencial un crisol idóneo para fortalecerse. Todo lo cual, sin duda alguna, explicará por siempre el legado de su producción crítica. Pues Lía testimoniaba, a diario, la felicidad de trabajar incansablemente, de pensar, de sentir curiosidad.

Es de plena justicia señalar que Lía fue una de las más insignes quevedistas de nuestro tiempo: Metáfora y sátira en la obra de Quevedo (1984), Quevedo: discurso y representación (1986), Quevedo. Poesía selecta (1989) y Un Heráclito cristiano, Canta sola a Lisi y otrospoemas (1998) -ambos dos en coautoría con Ignacio Arellanoo Quevedo a nueva luz: escritura y política -coedición preparada con Antonio Carreira- (1997) fueron sus primeros grandes aportes. Y resultó elegida, por la Editorial Castalia, para elaborar la edición crítica anotada de La Fortuna con seso y La Hora de todos (2003) en el proyecto general de las Obras completas en prosa. Pero sus lecturas, con todo, no se ciñeron a este autor. En 2005 seleccionó, para la Universidad de Málaga, trabajos previos sobre muy varios autores cuya especificidad dilucidaba en el diálogo con los clásicos griegos y latinos (De Fray Luis a Quevedo. Lecturas de los clásicos antiguos) en tanto que, en 2013, la Universidad de Salamanca editó Bartolomé Leonardo de Argensola y la sátira. Cinco ensayos.

Colegas y discípulos de todas las latitudes le rindieron tributo, en el año 2019, con el volumen de homenaje Docta y sabia Atenea. Studia in honorem Lia Schwartz. Los videos grabados en la presentación neoyorquina la muestran feliz y agradecida e igualmente entusiasmada por seguir pensando, leyendo y estudiando a sus autores dilectos.

Por eso, es por lo que pienso que, como ocurre con todos los grandes maestros, su finitud no será tal, pues siempre estará viva y actual en sus escritos. Por eso mismo, también, creo adecuado enfatizar que la literatura la hizo muy feliz y que ella misma, al pensar en su obra, bien podría haber remedado a su querido Horacio diciéndose "non omnis moriar".

Gracias, por tanto, querida Lía, descansa en paz. 